\title{
Performance of potato clones for processing in subtropical and high-altitude tropical regions of Brazil
}

Giovani Olegario da Silva ${ }^{1}$, Agnaldo Donizete Ferreira de Carvalho ${ }^{1}$, Gabriel Emiliano Pereira ${ }^{2}$, Carlos Francisco Ragassi ${ }^{1}$, Antônio César Bortoletto ${ }^{3}$, Elcio Hirano ${ }^{3}$, Arione da Silva Pereira ${ }^{3}$

${ }^{1}$ Embrapa Hortaliças, Brasília, DF. ${ }^{2}$ Universidade de Brasilia - UNB, DF. ${ }^{3}$ Embrapa Clima Temperado, Brasília, DF. Email: giovani.olegario@embrapa.br

\begin{abstract}
This work evaluated the performance of potato clones for some agronomic and processing traits, in subtropical and high-altitude tropical regions, under conventional and organic production systems. Experiments were conducted in spring of 2017 and 2018 in Canoinhas-SC (subtropical), under the conventional system, and in winter of 2018 and 2019 in Brasília-DF (tropical), Brazil, under conventional and organic systems. Eleven advanced clones and cultivars Agata (fresh), Atlantic (chipping) and Asterix (French fry) were evaluated. RCBD with tree replications was used, and tuber yield and processing traits, plant vigor and cycle were evaluated. It was not possible to select high yielding and good processing quality clones with short cycle and less vigorous plants. It because higher yield and larger tuber size were attained by longer cycle genotypes, which had higher specific gravity, but darker frying color. The most outstanding clones differed with region and production system. For chipping, in the subtropical region, no clone had adequate quality, but in tropical F177-11-20 presented similar processing traits and higher or similar yield to 'Atlantic' in both systems, and also ORG7785 in organic. Comparing with 'Asterix', for French fry, in the subtropical region, superior or similar to the standard this cultivar were F129-10-06 and F163-11-01; while in the tropical region and conventional system, were the clones ORG7785, F129-10-06, F163-11-01, F17711-20, ORG6464, ORG 6377, F05-11-03, Odone 80-02 and F174-11-01; and in organic system, the best clones were F54-11-03, ORG7785, F129-10-06, F163-11-01, F177-11-20 and ORG6464.
\end{abstract}

Keywords: cycle; fry color; Solanum tuberosum L.; specific gravity; tuber yield.

Seleção de clones de batata para processamento em regiões do Brasil de clima subtropical e tropical de altitude

\section{Resumo}

Neste trabalho foi avaliado o desempenho de clones de batata para caracteres agronômicos e de qualidade de processamento, em regiões subtropical e tropical de altitude, sob sistema convencional e orgânico de produção. Os experimentos foram conduzidos na primavera de 2017 e 2018 em Canoinhas-SC (subtropical), sobre sistema convencional, e nos invernos de 2018 e 2019 em Brasília-DF (tropical), Brasil, sob sistemas convencional e orgânico. Foram avaliados onze clones avançados e as cultivares Agata (mercado fresco), Atlantic (chips) e Asterix (palitos fritos). Foi utilizado delineamento em blocos casualisados com três repetições. Foram avaliados caracteres relacionados ao rendimento de tubérculos, qualidade de fritura, vigor de planta e ciclo vegetativo. Foi verificado que não foi possível selecionar clones com elevado rendimento de tubérculos e boa qualidade de fritura e com ciclo vegetativo precoce e com plantas menos vigorosas. Isso porque maior rendimento e maiores tamanhos de tubérculos foram associados com ciclo vegetativo mais longo, maior peso específico de tubérculos, porém cor mais escura de fritura. Os melhores clones diferiram com a região e sistemas de produção. Para chips, na região subtropical, nenhum clone apresentou bom desempenho, porém no ecossistema tropical, F177-11-20 apresentou similares qualidades industriais e maior ou superior produtividade em comparação com 'Atlantic' em ambos os sistemas de cultivo, também o clone ORG7785 no sistema orgânico. Para o mercado de fritura de palitos, portanto comparando com 'Asterix', na região subtropical, os clones F129-10-06 e F163-11-01 foram superiores ou equivalentes a esta cultivar; enquanto que na região tropical em sistema convencional destacam-se os 
clones ORG7785, F129-10-06, F163-11-01, F177-11-20, ORG6464, ORG 6377, F05-11-03, Odone 80-02 e F174-11-01; e nos sistema orgânico os clones F54-11-03, ORG7785, F129-10-06, F163-11-01, F177-11-20 e ORG6464.

Palavras-chave: ciclo vegetativo; cor de fritura; Solanum tuberosum L.; peso específico; rendimento de tubérculos.

\section{Introduction}

Although the potato is a typical coldweather crop, it is also grown in subtropical and tropical conditions. In Brazil, currently, most of the crop are carried out in the high-altitude tropical region, during the winter, when temperatures are lower and there is greater thermal amplitude between day and night, and in the subtropical region in two periods, spring and autumn (SILVA et al., 2020).

In Brazil, foreign potato cultivars predominate, which are developed under temperate climates with long photoperiod. These cultivars when planted in tropical or subtropical conditions suffer from changes in physiological processes. This is because higher temperatures and shorter photoperiod shorten the vegetative cycle, with a reduction in tuber yield and quality (HAVERKORT, 1990; KOOMAN et al., 1996; SILVA et al., 2020). For this reason, these cultivars are highly dependent on external inputs, mainly fertilizers, to maximize growth and express their yield potential in subtropical and tropical conditions (PEREIRA; SILVA, 2019).

Currently, the greatest demand for cultivars in Brazil is for industrial processing, and there are very few cultivars suitable for this purpose. Among the most important tuber trait required by the industry are high specific gravity, low content of reducing sugars and absence of tuber physiological disorders. The specific gravity influences the texture and flavor of the final product, as it is directly related to the dry mass content. The higher the dry mass content, the higher the yield in industrialization, the lower the fat absorption and the better the texture of the final product. While low levels of reducing sugars cause less darkening in the frying, improving the appearance and flavor of the product, which can be directly evaluated by the frying color (SILVA et al., 2014).

In addition to processing and tuber yield traits, the plant vigor and the vegetative cycle are of fundamental importance in the selection of superior potato clones. Long cycle genotypes
( $>130$ days) are generally more productive than the short cycle ones ( $<100$ days), probably due to the longer time to synthesize and store photoassimilates (SILVA; PINTO, 2005; RODRIGUES et al., 2009). On the other hand, short cycle cultivars are preferred by producers, as they allow for a greater number of crops throughout the year, in addition to the shorter time of exposure of plants to biotic and abiotic stresses and less demand for irrigation. As for the plant vigor, Silva et al. (2007) found positive correlations of medium magnitude of vigor with number and yield of tubers in the evaluation of a potato population in the field. Likewise, Pereira et al. (2017) reported positive correlations, ranging from medium to high, between plant vigor and total and marketable tuber yield, in an experiment of advanced potato clones, suggesting that more vigorous plants produce larger tubers, with greater number and higher yield. However, care should be taken in selecting for plant vigor, as there been shown that clones with very vigorous plants usually have a longer vegetative cycle (SILVA et al., 2007; LAMBORO et al., 2014).

Plants have their development affected by its genotype, the environment, and the interaction between them $(G \times E)$. The latter promotes significant differences in the performance of genotypes when they are grown under different environmental conditions (MOHAMMADI et al., 2007). Therefore, in order to identify the superiority and adaptation of genotypes, it is important to consider their responses to different environments.

Thus, the objective of this work was to evaluate the performance of advanced potato clones for tuber yield and processing quality traits, vegetative cycle and plant vigor in the subtropical region and in the high-altitude tropical region, under conventional and organic production systems. 


\section{Material and Methods}

The experiments were carried out in the subtropical region, in Canoinhas-SC $\left(26^{\circ} 10^{\prime} \mathrm{S}\right.$, $50.23^{\prime} \mathrm{W}, 839 \mathrm{~m}$ a.s.l.), in the spring seasons of 2017 and 2018, under conventional production system; and in the high-altitude tropical region, in Brasília-DF (15 $55^{\prime} \mathrm{S}, 48^{\circ} 08^{\prime} \mathrm{W}, 999 \mathrm{~m}$ a.s.l.), in the winter seasons of 2018 and 2019, under conventional and organic production systems. They were planted on 11 August 2017 and 9 August 2018, and harvested on 19 November 2017 and on 17 November 2018, respectively, in Canoinhas; and planted on 15 May 2018 and on 22 May 2019, and harvested on 23 August 2018 and on 30 August 2019, respectively, under conventional system, and planted on 20 June 2018 and on 24 June 2019, and harvested on 28 September 2018 and on 2 October 2019, respectively, under an organic system, in Brasilia.

A set of 11 advanced potato clones was evaluated in comparison with the check cultivars Agata, which is widely cultivated for the fresh market; Asterix, which is the main cultivar used for french fry processing; and Atlantic, the main cultivar used to make chips/string fries.

In the experiment carried out in Canoinhas in 2017, type IV seed tubers (minitubers of 23-30 mm diameter) were used, which had been stored for eight months in a cold chamber $\left(3.5 \pm 0.5^{\circ} \mathrm{C}\right)$. Type II tubers $(40-50 \mathrm{~mm}$ diameter) obtained in this experiment were stored in a cold chamber and used in the experiments carried out in 2018, in Canoinhas and Brasilia. Type II tubers, stored in a cold chamber, were used in the 2019 experiments.

A randomized complete block design with three replications was used. In Canoinhas, plots consisted of two rows with 10 plants each, spaced $0.75 \mathrm{~m}$ between rows and $0.35 \mathrm{~m}$ between plants. In Brasília, plots consisted of a single row of 10 plants, spaced $0.80 \mathrm{~m}$ between rows and $0.30 \mathrm{~m}$ between plants in the conventional system experiment, and single row of 15 plants, spaced $0.80 \mathrm{~m}$ between rows and $0.30 \mathrm{~m}$ between plants in the organic system experiment.

The fertilizers of the experiments in Canoinhas were applied in the planting furrow, with $120 \mathrm{~kg} \mathrm{ha}^{-1}$ of $\mathrm{N}, 420 \mathrm{~kg} \mathrm{ha}^{-1}$ of $\mathrm{P}_{2} \mathrm{O}_{5}$ and 240 $\mathrm{kg} \mathrm{ha}^{-1}$ of $\mathrm{K}_{2} \mathrm{O}$ of the formulae NPK 04-14-08. In Brasilia, in the conventional system experiment, fertilizers were applied in the planting furrow at a dose of $190 \mathrm{~kg} \mathrm{ha}^{-1}$ of $\mathrm{N}, 420 \mathrm{~kg} \mathrm{ha}^{-1}$ of $\mathrm{P}_{2} \mathrm{O}_{5}$ and $350 \mathrm{~kg} \mathrm{ha}^{-1}$ of $\mathrm{K}_{2} \mathrm{O}$, and sidedressing of $90 \mathrm{~kg}$ of $\mathrm{N}$ $\mathrm{ha}^{-1}$ when earthing up the plants; in the organic system, $28,750 \mathrm{~kg} \mathrm{ha}^{-1}$ of organic compost (COUTO et al., 2008) and $1,250 \mathrm{~kg} \mathrm{ha}^{-1}$ of thermophosphate were applied. The cultural and phytosanitary treatments followed the recommendations of respective regions and according to the production system.

The following agronomic traits were evaluated: plant vigor, vegetative cycle and tuber yield components. The plant vigor was evaluated by assigning scores from 1 to 9 for each plot (1higher vigor; 9- lower vigor), 70 days after planting, a period that coincides with the full flowering of most clones. The vegetative cycle was evaluated by assigning scores from 1 to 9 (1long; 9- short), at 100 days after planting. The tuber yield was evaluated by weighing the graded tubers of each plot. Tubers were graded according to their transverse diameter as marketable $(>45 \mathrm{~mm})$ and non-marketable $(\leq 45 \mathrm{~mm})$, and weighed, obtaining the total and marketable tuber mass $\left(\mathrm{kg}\right.$ plot $\left.^{-1}\right)$, and the average tuber mass obtained by the ratio between the total tuber mass and the total number of tubers.

For the processing quality traits, the specific gravity and frying color were evaluated. Specific gravity was assessed in marketable sized tuber samples, using a hydrometer from the Snack Food Association (Arlington, VA, USA). The frying color was assessed as chips, using samples of three healthy tubers of marketable size per plot. Fifteen $2.0 \mathrm{~mm}$ thick slices were obtained from sample, fried in vegetable oil, at an initial temperature of $180^{\circ} \mathrm{C}$ until the bubbling stopped. The fry color was evaluated visually, assigning scores from 1 to 9 (1- dark; 9- light), according to a methodology adapted from CIP (2010).

The tuber mass data were converted to $t$ $\mathrm{ha}^{-1}$. The data were subjected to individual and joint analysis of variance, analysis of grouping of means by the Scott \& Knott test, and simple correlations. Statistical analyzes were performed using the Genes computer software (CRUZ, 2013).

\section{Results and Discussion}

The joint analysis of variance showed significant differences $(p<0.05)$ among genotypes for all traits. There were also significant effects of environment and genotype $x$ environment interaction for all traits, indicating that, in general, the genotypes had different 
performance in the tested environments (data not shown).

The coefficient of environmental variation (CV), which is indicative of experimental precision, was lower than 30\% for all yield traits, in both experiments, indicating good precision, considering that these traits are of a quantitative nature, and therefore suffer greater environmental influence than qualitative traits (SILVA et al., 2017). For processing quality traits, i.e., frying color and specific gravity, the $\mathrm{CV}$ values were lower, and the $\mathrm{CVg} / \mathrm{CV}$ ratio, which indicates the predominance of the variation of genetic order $(\mathrm{CVg})$ in relation to the environmental, was also close to or higher than unit for both traits in all experiment environments, indicating good reliability in the estimates. As for the plant traits, i.e., plant vigor and vegetative cycle, when observing the experimental precision and the $\mathrm{CVg} / \mathrm{CV}$ ratio, there is less reliability of the estimates for these two traits in Brasília under the conventional production system in 2018, whereas in the other experiment environments, either the $\mathrm{CV}$ was lower, or the $\mathrm{CVg} / \mathrm{CV}$ ratio was higher than the unit, indicating good reliability of the estimates (Tables 1, 2, 3 and 4).

For the marketable tuber yield, which is the most important component of yield, in Canoinhas in 2017, clones F05-11-03, F54-11-03, ORG 7785, Odone 80-02 and ORG 6377 formed the top yielding group, surpassing the three check cultivars (Table 1 ). The intermediate group was formed by clones F174-11-01, F129-10-06, F163-11-01 and F177-11-20, and the check cultivar for french fry, Asterix. In 2018, the vast majority of the genotypes were grouped together, with the exception of the clone ORG 6464 , which was less productive. 
Table 1. Means of marketable and total tuber yield of 11 advanced potato clones and three cultivars, in the spring seasons of 2017 and 2018 under conventional production system in Canoinhas-SC, and in the winter seasons of 2018 and 2019 under conventional and organic production systems, in Brasilia-DF, Brazil

\begin{tabular}{|c|c|c|c|c|c|c|}
\hline \multirow[t]{3}{*}{ Genotype } & \multirow{2}{*}{\multicolumn{2}{|c|}{$\begin{array}{c}\text { Canoinhas } \\
\text { Conventional system }\end{array}$}} & \multicolumn{4}{|c|}{ Brasilia } \\
\hline & & & \multicolumn{2}{|c|}{ Conventional system } & \multicolumn{2}{|c|}{ Organic system } \\
\hline & 2017 & 2018 & 2018 & 2019 & 2018 & 2019 \\
\hline & \multicolumn{6}{|c|}{ Marketable tuber yield ( $\mathrm{t} \mathrm{ha}^{-1}$ ) } \\
\hline F05-11-03 & 42.07 a $A$ & 17.22 a $B$ & 36.88 a $A$ & 33.88 b A & $19.67 \mathrm{~b} \mathrm{~B}$ & 13.92 a $B$ \\
\hline F54-11-03 & 39.23 a $A$ & 12.57 a B & 46.75 a $A$ & 48.67 a $A$ & 46.09 a $A$ & 17.42 a B \\
\hline ORG 7785 & 37.06 a B & 14.50 a C & 34.54 a B & 57.99 a $A$ & 37.93 a B & - \\
\hline Odone 80-02 & 34.22 a $A$ & 10.97 a $B$ & 37.14 a A & $28.52 \mathrm{~b} \mathrm{~A}$ & $26.86 \mathrm{~b} \mathrm{~A}$ & $6.68 \mathrm{~b} \mathrm{~B}$ \\
\hline ORG 6377 & 28.04 a B & 10.13 a C & 43.60 a $A$ & 49.39 а $\mathrm{A}$ & $25.30 \mathrm{~b} \mathrm{~B}$ & 16.14 a C \\
\hline F174-11-01 & $22.41 \mathrm{~b} \mathrm{~B}$ & 9.78 a C & 34.46 a B & 22.81 b B & $14.35 \mathrm{~b} \mathrm{C}$ & 9.48 b C \\
\hline Asterix & $22.30 \mathrm{~b} \mathrm{~A}$ & 11.73 a $B$ & 24.75 b A & $26.29 \mathrm{~b} \mathrm{~A}$ & $23.70 \mathrm{~b} \mathrm{~A}$ & 24.98 a $A$ \\
\hline F129-10-06 & 21.27 b B & 11.45 a B & 29.03 b A & $30.35 \mathrm{~b} \mathrm{~A}$ & 32.52 a $A$ & 17.44 a $B$ \\
\hline F163-11-01 & $20.40 \mathrm{~b} \mathrm{~A}$ & 9.96 a $\mathrm{A}$ & $18.00 \mathrm{~b} \mathrm{~A}$ & $22.67 \mathrm{~b} \mathrm{~A}$ & $22.60 \mathrm{~b} \mathrm{~A}$ & 18.62 a $A$ \\
\hline F177-11-20 & $20.10 \mathrm{~b} \mathrm{C}$ & 10.79 a C & 53.69 a $A$ & 43.21 a B & 35.16 a B & 12.46 a C \\
\hline ORG6 464 & 14.42 c C & $6.95 \mathrm{~b} \mathrm{C}$ & 30.36 b B & 54.70 a $A$ & $25.03 \mathrm{~b} \mathrm{~B}$ & 13.54 a C \\
\hline Atlantic & 11.43 с B & 11.28 a B & 39.81 a $A$ & $37.43 \mathrm{~b} \mathrm{~A}$ & 37.98 a A & - \\
\hline F162-11-05 & 9.18 c A & 14.32 a $\mathrm{A}$ & $24.75 \mathrm{~b} \mathrm{~A}$ & $12.70 \mathrm{~b} \mathrm{~A}$ & $15.90 \mathrm{~b} \mathrm{~A}$ & $6.95 \mathrm{~b} \mathrm{~A}$ \\
\hline Agata & 6.38 c B & 13.06 a B & $23.65 \mathrm{~b} \mathrm{~A}$ & $23.43 \mathrm{~b} \mathrm{~A}$ & $26.66 \mathrm{~b} \mathrm{~A}$ & 13.04 a B \\
\hline Means & 23.47 & 11.77 & 34.10 & 35.15 & 27.84 & 13.04 \\
\hline CV & 28.41 & 29.29 & 29.43 & 23.86 & 29.98 & 24.98 \\
\hline \multirow[t]{2}{*}{$\mathrm{CVg} / \mathrm{CV}$} & 1.60 & 0.43 & 0.80 & 1.53 & 0.92 & 2.29 \\
\hline & \multicolumn{6}{|c|}{ Total tuber yield $\left(\mathrm{t} \mathrm{ha}^{-1}\right)$} \\
\hline F05-11-03 & 49.44 a $\mathrm{A}$ & 22.24 a B & $45.08 \mathrm{~b} \mathrm{~A}$ & 56.12 a $A$ & 28.12 a B & 46.58 a $\mathrm{A}$ \\
\hline F54-11-03 & 45.17 a $A$ & 19.49 a C & 52.69 a $A$ & 59.33 а $\mathrm{A}$ & 50.17 a $A$ & $34.55 \mathrm{~b} \mathrm{~B}$ \\
\hline ORG 7785 & 42.46 a B & 20.14 a C & $45.17 \mathrm{~b} \mathrm{~B}$ & 72.11 a $\mathrm{A}$ & 44.86 a B & - \\
\hline Odone 80-02 & 42.27 a $A$ & 17.98 a B & 48.39 a $A$ & $44.49 \mathrm{~b} \mathrm{~A}$ & 38.27 a A & $35.09 \mathrm{~b} \mathrm{~A}$ \\
\hline ORG 6377 & 40.20 a B & 20.35 a C & 56.55 a $A$ & 63.91 a $A$ & 35.60 a B & 49.59 a $\mathrm{A}$ \\
\hline Asterix & 36.19 a $A$ & 21.16 a B & $37.58 \mathrm{~b} \mathrm{~A}$ & $42.29 \mathrm{~b} \mathrm{~A}$ & 30.75 a B & 28.97 c B \\
\hline F174-11-01 & 34.79 a B & 17.75 a C & 51.69 a A & 39.02 b B & 22.20 a C & 18.83 с C \\
\hline F129-10-06 & 29.21 b B & 19.52 a B & $39.67 \mathrm{~b} \mathrm{~A}$ & 41.04 b A & 39.03 a A & 42.53 a $A$ \\
\hline F177-11-20 & 29.11 b C & 18.09 a C & 64.93 a A & 60.24 a $\mathrm{A}$ & 44.06 a B & 39.65 b B \\
\hline F163-11-01 & 27.17 b A & 19.64 a $\mathrm{A}$ & $31.67 \mathrm{~b} \mathrm{~A}$ & $38.10 \mathrm{~b} \mathrm{~A}$ & 30.23 a $A$ & $33.78 \mathrm{~b} \mathrm{~A}$ \\
\hline ORG 6464 & $21.03 \mathrm{~b} \mathrm{C}$ & 12.10 a C & 39.49 b B & 68.62 a $A$ & 34.44 a B & $36.65 \mathrm{~b} \mathrm{~B}$ \\
\hline Atlantic & 19.05 b B & 18.46 a B & $46.43 \mathrm{~b} \mathrm{~A}$ & $47.33 \mathrm{~b} \mathrm{~A}$ & 43.40 a $\mathrm{A}$ & - \\
\hline F162-11-05 & $18.63 \mathrm{~b} \mathrm{~A}$ & 25.56 a $A$ & $36.15 \mathrm{~b} \mathrm{~A}$ & $26.75 \mathrm{~b} \mathrm{~A}$ & 27.03 a A & $23.12 \mathrm{c} \mathrm{A}$ \\
\hline Agata & $16.35 \mathrm{~b} \mathrm{~B}$ & 24.58 a B & $36.39 \mathrm{~b} \mathrm{~A}$ & $41.86 \mathrm{~b} \mathrm{~A}$ & 35.75 a A & 19.85 с B \\
\hline Mean & 32.22 & 19.79 & 45.13 & 50.09 & 35.99 & 34.10 \\
\hline CV & 22.38 & 19.04 & 22.06 & 19.45 & 24.08 & 17.26 \\
\hline $\mathrm{CVg} / \mathrm{CV}$ & 1.39 & 0.63 & 0.72 & 1.24 & 0.70 & 1.50 \\
\hline
\end{tabular}

Means followed by the same lowercase letter in the column and uppercase in the row belong to the same group by the Scott and Knott test at 5\% probability of error. CV: coefficient of environmental variation. $\mathrm{CVg} / \mathrm{CV}$ : rate between genotypic and environmental coefficient of variation.

In Brasilia, the performance of the clones in the conventional system was better, $34.10 \mathrm{t} \mathrm{ha}{ }^{-}$ ${ }^{1}$ and $35.15 \mathrm{t} \mathrm{ha}^{-1}$, and more consistent than in the organic system, $27.84 \mathrm{t} \mathrm{ha}^{-1}$ and $13.04 \mathrm{t} \mathrm{ha}^{-1}$, in 2018 and 2019, respectively. In the conventional system, clones F177-11-20, F54-1103, ORG 7785 and ORG 6377 were simultaneously in the upper groups of 2018 and 2019, followed by clones Odone 80-02, F174-1101, ORG 6464 and F05-11-03, and the check cultivar for chip processing, 'Atlantic' (Table 1). The other clones were grouped with 'Asterix' and the check cultivar for the fresh market, 'Agata'. In the organic system, clones F129-10-06, F54-11-03 
and F177-11-20 showed the highest marketable tuber yields in both years, 2018 and 2019, and were grouped with the cultivar Atlantic in the first year, and with clones F05-11-03, F163-11-01, ORG 6464 and ORG 6377, Agata and 'Asterix' in the second year. Therefore, in the organic system, not all clones with the best performance in marketable yield coincided with those observed in the conventional system. By the groupings of means between the experiments, it appears that mainly the clones ORG 6377, F0511-03, F174-11-01 did not stand out in the organic system.

The less concentrated and less soluble supply of nutrients from organic fertilizers is one of the main causes of the low productivity of the potato crop in an organic production system compared to the conventional system (PALMER et al., 2013). There are also differences in relation to disease control, where potato genotypes more resistant to diseases such as late blight (Phytophthora infestans) and early blight (Alternaria spp.), tend to perform better in the organic system than more susceptible ones. However, this was not the case in the present study, as the occurrence of these diseases in the organic system was not found. The potato crop has a short cycle, usually less than 100 days since planting, and the phase of greater macronutrient absorption occurs in the tuber filling period, approximately between 42 to 70 days after planting, therefore there is a high demand for nutrients in a short time (FERNANDES et al., 2011). It is also a species of plant known to be very responsive to investment in fertilization (MALLMANN et al., 2012). In a study reported by
Silva et al. (2017), with 13 advanced clones and the cultivars Agata and Asterix, evaluated in organic and conventional production systems in the high-altitude tropical region of Brasília, a great variation in marketable tuber yield of the different genotypes was observed in organic system ( 3.50 to $38.75 \mathrm{t} \mathrm{ha}^{-1}$ ), with an average of $13.50 \mathrm{t} \mathrm{ha}^{-1}$, while in a conventional production system carried out in a nearby area, the average yield was $21.66 \mathrm{t} \mathrm{ha}^{-1}$.

Regarding the total tuber production, in Canoinhas, clones F05-11-03, F54-11-03, ORG 7785, Odone 80-02, ORG 6377, and F174-11-01, together with 'Asterix', formed the first upper group (Table 1). In Brasilia, in conventional production, the most productive group simultaneously in 2018 and 2019 was composed by clones F177-11-20, ORG 6377 and F54-11-03, overcoming the three checks, whereas in the organic system, ORG 6377, F129-10-06 and F0511-03, ORG 7785, and 'Atlantic' were in the top group (Table 1).

For average tuber mass, in Canoinhas, in the two years simultaneously, F54-11-03, ORG 7785 presented the largest tubers (Table 2). In Brasilia, in the conventional system, the upper group was composed of clones F54-11-03, ORG 7785, ORG 6464, F129-10-06 and ORG 6377, and 'Atlantic' (Table 2). The other clones were grouped with 'Asterix' and 'Agata'. In the organic system the first group had F54-11-03, ORG7785, F05-11-03, F129-10-06, 163-11-01, F177-11-20, and 'Atlantic'. 
Table 2. Means of average tuber mass of 11 advanced potato clones and three cultivars, in the spring seasons of 2017 and 2018 under conventional production system in Canoinhas-SC, and in the winter seasons of 2018 and 2019 under conventional and organic production systems, in Brasilia-DF, Brazil

\begin{tabular}{|c|c|c|c|c|c|c|}
\hline \multirow[t]{3}{*}{ Genotype } & \multirow{2}{*}{\multicolumn{2}{|c|}{$\begin{array}{c}\text { Canoinhas } \\
\text { Conventional system }\end{array}$}} & \multicolumn{4}{|c|}{ Brasilia } \\
\hline & & & \multicolumn{2}{|c|}{ Conventional system } & \multicolumn{2}{|c|}{ Organic system } \\
\hline & 2017 & 2018 & 2018 & 2019 & 2018 & 2019 \\
\hline & \multicolumn{6}{|c|}{ Average tuber mass (g) } \\
\hline F54-11-03 & 190.75 a B & 72.04 a D & 159.37 a C & $146.40 \mathrm{a} \mathrm{C}$ & 248.40 a A & 203.30 a B \\
\hline ORG 7785 & 172.42 a B & 78.87 a D & 128.54 a C & 158.39 a A & 225.14 a A & - \\
\hline Odone 80-02 & 153.89 b B & $58.93 \mathrm{~b} C$ & 131.99 a B & 93.50 b C & 169.43 b A & 186.88 a $A$ \\
\hline F05-11-03 & 138.31 b B & 81.26 a C & 133.02 a B & $108.83 \mathrm{~b} \mathrm{C}$ & 213.54 a A & 190.37 a A \\
\hline ORG 6377 & 113.39 c B & $51.18 \mathrm{~b} \mathrm{C}$ & 109.75 a B & 143.01 a A & 164.57 b A & 180.21 a A \\
\hline F129-10-06 & 111.40 c B & $58.17 \mathrm{~b} \mathrm{C}$ & 122.03 a $B$ & 120.98 a B & 201.01 a $A$ & 174.00 a $A$ \\
\hline F174-11-01 & 107.66 c B & 61.06 b C & 128.37 a $A$ & 102.54 b B & 142.17 b A & 149.14 a $A$ \\
\hline F177-11-20 & 106.19 c B & $58.92 \mathrm{~b} C$ & 147.38 a $A$ & 115.09 b B & 189.80 a $\mathrm{A}$ & 175.28 a A \\
\hline F163-11-01 & 98.73 с B & 63.31 b B & 102.12 a B & 98.03 b B & 201.42 a A & 186.97 a A \\
\hline Atlantic & 95.12 c C & 69.30 a C & 140.57 a B & 133.30 a B & 201.49 a A & - \\
\hline ORG 6464 & 94.09 с B & $52.34 \mathrm{~b} \mathrm{C}$ & 127.72 a $A$ & 133.21 a A & 169.15 b A & 152.61 a $A$ \\
\hline Asterix & 91.13 с B & $55.21 \mathrm{~b} \mathrm{C}$ & 105.06 a B & 102.27 b B & 169.91 b A & 163.45 a $A$ \\
\hline F162-11-05 & $78.70 \mathrm{~d} B$ & 60.59 b B & 102.17 a $B$ & 77.55 b B & $143.56 \mathrm{~b} \mathrm{~A}$ & 134.27 a A \\
\hline Agata & $53.30 \mathrm{~d} \mathrm{~B}$ & $60.21 \mathrm{~b} \mathrm{~B}$ & 87.34 a B & 80.78 b B & $158.59 \mathrm{~b} \mathrm{~A}$ & 144.13 a A \\
\hline Mean & 114.65 & 62.95 & 123.24 & 115.28 & 185.58 & 170.05 \\
\hline CV & 16.95 & 12.57 & 21.21 & 14.68 & 15.53 & 15.92 \\
\hline $\mathrm{CVg} / \mathrm{CV}$ & 1.83 & 1.01 & 0.49 & 1.35 & 0.92 & 0.74 \\
\hline
\end{tabular}

Means followed by the same lowercase letter in the column and uppercase in the row belong to the same group by the Scott and Knott test at $5 \%$ probability of error. CV: coefficient of environmental variation. CVg / CV: rate between genotypic and environmental coefficient of variation.

Thus, with reference to marketable tuber yield and average tuber masses together, in the subtropical region, clones F54-11-03 and ORG 7785 performed better (Tables 1 and 2). In the high-altitude tropical region, in the conventional system, the superior group had F54-11-03, ORG 7785 and ORG 6377, while in the organic system, F129-10-06, F177-11-20, F54-11-03, ORG 7785, and 'Atlantic'.

Regarding plant vigor, simultaneously in 2017 and 2018, in Canoinhas, F177-11-20, Odone 80-02, F162-11-05, F129-10-06, 'Atlantic', and 'Agata' formed the group of less vigorous clones, followed by the group of other clones and 'Asterix' (Table 3). In Brasilia, in the conventional system, clones F177-11-20, Odone 80-02, ORG 6464, F05-11-03, F54-11-03 and ORG 7785, and checks 'Atlantic' and 'Asterix' constituted the group of genotypes of less plant vigor. The remaining clones and 'Agata' formed the group of more vigorous plants. In the organic system, no clone was in the top group for less vigor plants, which had checks 'Agata' and 'Atlantic'; and the intermediate group was composed by F162-1105, F174-11-01 and F163-11-01, and 'Asterix'. 
Table 3. Means of plant vigor and vegetative cycle scores of 11 advanced potato clones and three cultivars, in the spring seasons of 2017 and 2018 under conventional production system, in Canoinhas-SC, and in the winter seasons of 2018 and 2019 under conventional and organic production systems, in Brasilia-DF, Brazil

\begin{tabular}{|c|c|c|c|c|c|c|}
\hline \multirow{3}{*}{ Genotype } & \multirow{2}{*}{\multicolumn{2}{|c|}{$\begin{array}{c}\text { Canoinhas } \\
\text { Conventional system }\end{array}$}} & \multicolumn{4}{|c|}{ Brasilia } \\
\hline & & & \multicolumn{2}{|c|}{ Conventional system } & \multicolumn{2}{|c|}{ Organic system } \\
\hline & 2017 & 2018 & 2018 & 2019 & 2018 & 2019 \\
\hline & \multicolumn{6}{|c|}{ Plant vigor (1- high vigor; 9- low vigor) } \\
\hline F177-11-20 & 4.33 a $\mathrm{A}$ & 3.00 a B & 4.00 a $\mathrm{A}$ & 3.33 a B & $1.00 \mathrm{~b} \mathrm{C}$ & 1.67 c C \\
\hline Odone 80-02 & 4.00 a A & 3.00 a B & 3.00 a B & 3.33 a $A$ & 2.83 a B & 2.17 c B \\
\hline Atlantic & 3.67 a $A$ & 3.00 a $A$ & 3.67 a $\mathrm{A}$ & 3.33 a $A$ & 2.33 a B & - \\
\hline F163-11-01 & 3.67 a $A$ & $2.67 \mathrm{~b} \mathrm{~B}$ & 3.67 a $A$ & $3.00 \mathrm{~b} \mathrm{~B}$ & 2.33 a B & $2.83 \mathrm{~b} \mathrm{~B}$ \\
\hline F162-11-05 & 3.33 a $\mathrm{A}$ & 3.00 a $A$ & 3.67 a $A$ & $2.33 \mathrm{~b} \mathrm{~B}$ & 2.33 a B & $3.00 \mathrm{~b} \mathrm{~A}$ \\
\hline Agata & 3.33 a C & 3.00 a C & 2.67 a C & $2.33 \mathrm{~b} \mathrm{C}$ & 3.67 a B & 4.67 a $\mathrm{A}$ \\
\hline F129-10-06 & 3.00 a B & 3.00 a B & 4.00 a $A$ & $3.00 \mathrm{~b} \mathrm{~B}$ & 2.50 a B & 1.33 c C \\
\hline ORG 6464 & $2.67 \mathrm{~b} \mathrm{~B}$ & 3.67 a $A$ & 3.67 a A & 4.00 a $\mathrm{A}$ & $2.00 \mathrm{~b} \mathrm{~B}$ & 1.17 c C \\
\hline F05-11-03 & $2.67 \mathrm{~b} \mathrm{C}$ & 3.00 a B & 3.33 a B & 4.33 a $A$ & 2.33 a C & 1.33 c D \\
\hline F54-11-03 & $2.00 \mathrm{~b} \mathrm{~B}$ & 3.00 a A & 3.00 a A & 3.67 a A & 2.83 a A & 1.50 c B \\
\hline F174-11-01 & $2.00 \mathrm{~b} \mathrm{~A}$ & 3.00 a $A$ & 3.00 a $A$ & $2.33 \mathrm{~b} \mathrm{~A}$ & 2.67 a $A$ & $3.00 \mathrm{~b} \mathrm{~A}$ \\
\hline ORG 7785 & $2.00 \mathrm{~b} \mathrm{C}$ & 3.00 a B & 4.00 a $A$ & 4.00 a $A$ & $1.50 \mathrm{~b} \mathrm{C}$ & - \\
\hline ORG 6377 & $1.67 \mathrm{~b} \mathrm{~B}$ & 3.00 a $A$ & 3.67 a $\mathrm{A}$ & $3.00 \mathrm{~b} \mathrm{~A}$ & 2.50 a $\mathrm{A}$ & 1.33 с B \\
\hline Asterix & $1.67 \mathrm{~b} \mathrm{~B}$ & $2.33 \mathrm{~b} \mathrm{~B}$ & 3.00 a A & 3.33 a A & 3.00 a A & $2.67 \mathrm{~b} \mathrm{~A}$ \\
\hline Mean & 2.86 & 2.98 & 3.45 & 3.24 & 2.42 & 2.22 \\
\hline CV & 19.59 & 8.51 & 20.18 & 15.47 & 18.47 & 30.03 \\
\hline \multirow[t]{2}{*}{$\mathrm{CVg} / \mathrm{CV}$} & 1.49 & 0.92 & 0.27 & 1.12 & 1.32 & 1.39 \\
\hline & \multicolumn{6}{|c|}{ Vegetative cycle (1- long; 9- short) } \\
\hline Agata & 9.00 a $A$ & 8.00 a $A$ & $2.33 \mathrm{cC}$ & 7.00 a $A$ & - & 5.00 a B \\
\hline Atlantic & 9.00 a A & 8.00 a $A$ & 1.00 c B & $1.67 \mathrm{~b} \mathrm{~B}$ & - & - \\
\hline F163-11-01 & $7.33 \mathrm{~b} \mathrm{~A}$ & $7.33 \mathrm{~b} \mathrm{~A}$ & 1.00 c B & $1.67 \mathrm{~b} \mathrm{~B}$ & - & 1.00 c B \\
\hline Asterix & $7.00 \mathrm{~b} \mathrm{~A}$ & 8.00 a $A$ & 9.00 a A & 6.00 a $A$ & - & $3.00 \mathrm{~b} \mathrm{~B}$ \\
\hline F174-11-01 & $7.00 \mathrm{~b} \mathrm{~A}$ & $7.00 \mathrm{~b} \mathrm{~A}$ & 3.67 c B & 6.00 a $A$ & - & 6.00 a $A$ \\
\hline F162-11-05 & $6.67 \mathrm{~b} \mathrm{~A}$ & $6.67 \mathrm{~b} \mathrm{~A}$ & $5.00 \mathrm{~b} \mathrm{~B}$ & 7.00 a $A$ & - & $3.00 \mathrm{~b} \mathrm{~B}$ \\
\hline F129-10-06 & $6.33 \mathrm{~b} \mathrm{~A}$ & $6.33 \mathrm{~b} \mathrm{~A}$ & 2.33 с B & 6.00 a $A$ & - & $3.00 \mathrm{~b} \mathrm{~B}$ \\
\hline F05-11-03 & $6.33 \mathrm{~b} \mathrm{~A}$ & $5.00 \mathrm{c} \mathrm{B}$ & $5.00 \mathrm{~b} \mathrm{~B}$ & 7.00 a A & - & $3.00 \mathrm{~b} \mathrm{~B}$ \\
\hline ORG 6377 & 3.00 c B & 8.00 a $A$ & 1.00 c B & $3.33 \mathrm{~b} \mathrm{~A}$ & - & 1.67 c B \\
\hline Odone 80-02 & $1.67 \mathrm{~d} \mathrm{~B}$ & $6.67 \mathrm{~b} \mathrm{~A}$ & 2.33 с B & 6.00 a $A$ & - & $3.00 \mathrm{~b} \mathrm{~B}$ \\
\hline ORG 7785 & $1.33 \mathrm{~d} \mathrm{~B}$ & $4.00 \mathrm{cA}$ & 1.00 c B & $1.00 \mathrm{~b} \mathrm{~B}$ & - & - \\
\hline F177-11-20 & $1.00 \mathrm{~d} \mathrm{~B}$ & $4.00 \mathrm{c} \mathrm{A}$ & $2.33 \mathrm{CB}$ & 5.00 a $A$ & - & $3.00 \mathrm{~b} \mathrm{~B}$ \\
\hline F54-11-03 & $1.00 \mathrm{~d} \mathrm{~B}$ & 3.67 c A & 1.00 c B & $1.00 \mathrm{~b} \mathrm{~B}$ & - & 1.00 c B \\
\hline ORG 6464 & $1.00 \mathrm{~d} \mathrm{~A}$ & $1.33 \mathrm{~d} \mathrm{~A}$ & $2.33 \mathrm{cA}$ & $3.00 \mathrm{~b} \mathrm{~A}$ & - & $1.00 \mathrm{c} \mathrm{A}$ \\
\hline Means & 4.83 & 6.00 & 2.81 & 4.4 & - & 2.81 \\
\hline CV & 12.98 & 12.16 & 37.45 & 41.62 & - & 25.06 \\
\hline $\mathrm{CVg} / \mathrm{CV}$ & 4.97 & 2.78 & 0.71 & 1.15 & - & 2.27 \\
\hline
\end{tabular}

Means followed by the same lowercase letter in the column and uppercase in the row belong to the same group by the Scott and Knott test at $5 \%$ probability of error. CV: coefficient of environmental variation. $\mathrm{CVg} / \mathrm{CV}$ : rate between genotypic and environmental coefficient of variation.

Regarding vegetative cycle, in Canoinhas, considering the two years together, it appears that the clones had longer cycle than checks (Tables 3), and among the clones, the least long cycle were F163-11-01, F174-11-01, F162-11-05, and F129-10-06. In Brasilia, in the conventional system, 'Agata' was the shortest cycle genotype, followed by F162-11-05 and F05-11-03. In the organic system, F174-11-01 and 'Agata' showed the shortest cycle, followed by the group formed by F162-11-05, F129-10-06, F05-11-03, Odone 8002, F177-11-20, and 'Asterix'.

Regarding specific gravity, the means of all six experiments for the checks were 1.072 for 
'Asterix', 1.082 for 'Atlantic', and 1.056 for 'Agata'. These values were slightly lower than those reported by Pereira et al. (2015), 1.083 and 1.092 for 'Asterix' and 'Atlantic', respectively, in assessments carried out in the subtropical region of Brazil. In the present study, in Canoinhas, F177-11-20 (1.085 in 2017; 1.081 in 2018) stood out as the only clone in the upper group, followed by 'Atlantic' (Table 4). Other clones with specific gravity higher or similar to 'Asterix' were F54-11-03, F162-11-05, F129-10-06, F174-11-01, Odone 80-02, ORG 7785 and F163-11-01.

Table 4. Means of specific gravity and chip color score of 11 advanced potato clones and three cultivars, in the spring seasons of 2017 and 2018 under conventional production system in Canoinhas-SC, and in the winter seasons of 2018 and 2019 under systems conventional and organic production, in Brasilia-DF, Brazil

\begin{tabular}{|c|c|c|c|c|c|c|}
\hline \multirow[t]{3}{*}{ Genotype } & \multirow{2}{*}{\multicolumn{2}{|c|}{$\begin{array}{c}\text { Canoinhas } \\
\text { Conventional system }\end{array}$}} & \multicolumn{4}{|c|}{ Brasilia } \\
\hline & & & \multicolumn{2}{|c|}{ Conventional system } & \multicolumn{2}{|c|}{ Organic system } \\
\hline & 2017 & 2018 & 2018 & 2019 & 2018 & 2019 \\
\hline & \multicolumn{6}{|c|}{ Specific gravity } \\
\hline Atlantic & 1.086 a $\mathrm{A}$ & $1.076 \mathrm{~b} \mathrm{~A}$ & 1.084 a $\mathrm{A}$ & - & 1.082 a A & - \\
\hline F177-11-20 & 1.085 a $\mathrm{A}$ & 1.081 a A & 1.086 a $\mathrm{A}$ & - & 1.088 a A & 1.083 \\
\hline F54-11-03 & 1.081 b A & 1.070 с A & 1.076 b A & - & 1.079 a A & 1.087 \\
\hline F162-11-05 & 1.080 c A & 1.072 с A & $1.073 \mathrm{~b} \mathrm{~A}$ & - & 1.080 a $\mathrm{A}$ & 1.075 \\
\hline F129-10-06 & 1.080 c A & $1.067 \mathrm{~d} \mathrm{C}$ & 1.075 b B & - & $1.074 \mathrm{~b} \mathrm{~B}$ & 1.083 \\
\hline F174-11-01 & $1.078 \mathrm{~d} \mathrm{~A}$ & $1.067 \mathrm{~d} \mathrm{~B}$ & 1.084 a A & - & 1.080 a A & 1.086 \\
\hline Odone 80-02 & $1.077 \mathrm{~d} \mathrm{~A}$ & 1.071 с A & 1.076 b A & - & $1.073 \mathrm{~b} \mathrm{~A}$ & 1.076 \\
\hline ORG7785 & $1.077 \mathrm{~d} A$ & 1.069 c B & 1.085 a $\mathrm{A}$ & - & 1.078 a A & - \\
\hline F163-11-01 & $1.077 \mathrm{~d} A$ & $1.068 \mathrm{~d} \mathrm{~B}$ & $1.071 \mathrm{~b} \mathrm{~A}$ & - & $1.077 \mathrm{~b} \mathrm{~A}$ & 1.080 \\
\hline Asterix & 1.076 e $A$ & $1.065 \mathrm{~d} \mathrm{~B}$ & 1.076 b A & - & $1.070 \mathrm{~b} \mathrm{~A}$ & 1.069 \\
\hline ORG 6377 & $1.071 \mathrm{f} \mathrm{A}$ & $1.068 \mathrm{~d} \mathrm{~B}$ & $1.072 \mathrm{~b} \mathrm{~A}$ & - & 1.066 c B & 1.075 \\
\hline ORG 6464 & 1.067 f B & $1.067 \mathrm{~d} \mathrm{~B}$ & 1.077 b A & - & 1.080 a A & 1.071 \\
\hline F05-11-03 & 1.067 f B & $1.065 \mathrm{~d} A$ & 1.079 a B & - & 1.065 c B & 1.072 \\
\hline Agata & $1.062 \mathrm{~g} \mathrm{~A}$ & 1.055 e A & $1.058 \mathrm{c} \mathrm{A}$ & - & 1.053 c A & 1.053 \\
\hline Mean & 1.080 & 1.070 & 1.080 & - & 1.070 & 1.076 \\
\hline CV & 0.18 & 0.07 & 0.41 & - & 0.36 & - \\
\hline \multirow[t]{2}{*}{$\mathrm{CVg} / \mathrm{CV}$} & 3.45 & 2.65 & 1.52 & - & 2.22 & - \\
\hline & \multicolumn{6}{|c|}{ Chip color (1- dark; 9- light) } \\
\hline Atlantic & 7.00 a A & 7.67 a $A$ & $7.40 \mathrm{~b} \mathrm{~A}$ & - & - & - \\
\hline F05-11-03 & 7.00 a $A$ & 7.67 a $A$ & 6.70 c A & - & - & 7.00 \\
\hline F163-11-01 & 6.33 а $A$ & 7.67 a $A$ & 6.87 с A & - & - & 7.00 \\
\hline F162-11-05 & 6.33 а $A$ & 7.33 a A & 6.63 с A & - & - & 6.60 \\
\hline Asterix & 6.33 a A & 6.00 a A & 5.63 с A & - & - & 7.00 \\
\hline ORG 6377 & 6.00 a B & 7.33 a A & 7.40 b A & - & - & 7.00 \\
\hline F129-10-06 & 6.00 a B & 7.67 a A & 7.60 b A & - & - & 7.00 \\
\hline Odone 80-02 & 5.67 b B & 8.00 a A & 7.03 с A & - & - & 7.00 \\
\hline F54-11-03 & 5.67 b C & 7.00 a B & 8.93 а $A$ & - & - & 7.00 \\
\hline F174-11-01 & 5.67 b B & 7.00 a A & 6.83 c A & - & - & 6.80 \\
\hline F177-11-20 & 5.33 b B & 7.67 a A & $7.60 \mathrm{~b} \mathrm{~A}$ & - & - & 9.00 \\
\hline ORG 7785 & 5.33 b B & 7.33 a A & 6.23 c B & - & - & - \\
\hline ORG 6464 & 4.67 c B & 4.67 b B & 7.53 b A & - & - & 7.00 \\
\hline Agata & $4.00 \mathrm{c} \mathrm{B}$ & $3.33 \mathrm{c} \mathrm{B}$ & $4.93 \mathrm{~d} \mathrm{~A}$ & - & - & 5.60 \\
\hline Mean & 5.81 & 6.88 & 7.00 & - & - & 7.00 \\
\hline $\mathrm{CV}$ & 10.5 & 8.37 & 19.90 & - & - & - \\
\hline $\mathrm{CVg} / \mathrm{CV}$ & 1.22 & 2.25 & 0.96 & - & - & - \\
\hline
\end{tabular}

Means followed by the same lowercase letter in the column and uppercase in the row belong to the same group by the Scott and Knott test at $5 \%$ probability of error. CV: coefficient of environmental variation. $\mathrm{CVg} / \mathrm{CV}$ : rate between genotypic and environmental coefficient of variation. 
According to Pádua et al. (2010), in relation to the industry requirements regarding dry matter content or specific gravity, depends on the type of product. For the french fry production it ranges from 18 to $24 \%$ (specific gravity of 1.070 to 1.097), whereas for chip production, a higher content is required, between 20 and $24 \%$ (specific gravity of 1.077 to 1.097), due to its higher surface / volume ratio, which increases absorption and superficial oil retention.

Chip color score means were 6.90 for Atlantic, the main cultivar used in the chip industry, 6.24 for Asterix, a cultivar widely used in the French fry industry, and 4.46 for 'Agata', the most important cultivar for the fresh market (Table 4). These means were slightly lower (darker) than 7.63 for 'Atlantic' and 5.38 for 'Asterix', reported by Silva et al. (2019). Therefore, the classification of check cultivars in relation to the specific gravity and chip color was as expected, indicating that the environments were favorable for the expression of these traits and highlighting the importance of evaluating frying color patterns used by the industry in the selection of superior clones.

In Canoinhas, clones F05-11-03, F163-1101, F162-11-05, ORG 6377 and F129-10-06, and checks 'Atlantic' and 'Asterix' were in the upper group of chip color the two years simultaneously (Table 4).

In Brasília, in the conventional production system, clone F54-11-03 had the best chip color, followed by the group of clones F177-11-20, F129-10-06, ORG 6464 and ORG 6377, and 'Atlantic' (Table 4). F05-11-03, F163-11-01, F16211-05, Odone 80-02, F174-11-01, ORG 7785, and 'Asterix' formed the intermediate group. In the organic system, the absolute best chip color was presented by the clone F177-11-20.

Therefore, regarding processing quality traits, i.e., chip color and specific gravity, none of the clones showed outstanding or similar quality to 'Atlantic' for the chip processing industry in the subtropical region, while the clone F177-1120 showed quality for chipping similar to 'Atlantic', in the high-altitude tropical region.

Regarding quality for french fry processing, the clones with the best or similar quality traits to 'Asterix' were F162-11-05, F12910-06 and F163-11-01, in the subtropical region, and F177-11-20, F54-11-03, F129-10-06, Odone 80-02, ORG 7785, F163-11-01 and F05-11-03, in the high-altitude tropical region.

Results of this work show that is difficult to identify high yielding genotypes, with good frying quality, and at the same time, short cycle and not very vigorous plants. To better understand this relationship, a simple correlation analysis between the characters was performed.

Correlation coefficients among these traits suggest that more productive genotypes tend to have a higher specific gravity, but darker frying color, with the two processing quality traits not correlating with each other. The most productive genotypes were those with less vigorous plants and longer vegetative cycle, but with no correlation between these two later traits. Higher average tuber mass and specific gravity were observed in genotypes with more vigorous plants and longer vegetative cycle. Genotypes with larger tubers had higher specific gravity. Lighter-colored chips was observed in genotypes with a shorter vegetative cycle and with higher plant vigor (Table 5).

Table 5. Simple correlations among yield traits, frying quality traits, plant vigor and vegetative cycle, for 11 advanced potato clones and three cultivars, in two harvests in conventional production system in Canoinhas-SC, and two harvests in conventional and organic production system in Brasilia-DF, Brazil

\begin{tabular}{lcccccc}
\hline & MTY & TTY & ATM & SE & Color & Vigor \\
\hline TTY & $0.91^{*}$ & & & & & \\
ATM & $0.50^{*}$ & $0.56^{*}$ & & & & \\
SE & $0.37^{*}$ & $0.38^{*}$ & $0.46^{*}$ & & & \\
Color & $-0.47^{*}$ & $-0.41^{*}$ & -0.07 & 0.02 & & \\
Vigor & $0.22^{*}$ & 0.07 & $-0.38^{*}$ & $-0.23^{*}$ & $-0.42^{*}$ & \\
Cycle & $-0.45^{*}$ & $-0.48^{*}$ & $-0.54^{*}$ & $-0.43^{*}$ & $0.25^{*}$ & 0.05 \\
\hline
\end{tabular}

MTY: marketable tuber yield; TTY: total tuber yield; ATM: average tuber mass; SG: specific gravity; Color: frying color; Vigor: plant vigor; Cycle: vegetative cycle. ${ }^{*}$ Significant at $5 \%$ probability of error by the $t$ test. 
The positive correlation between productivity and specific gravity, and negative with frying color, are in agreement with Silva et al. (2018), and between total tuber production and frying color, with Terres et al. (2012).

Regarding correlation of long vegetative cycle with higher tuber yield, higher specific gravity, darker frying color, larger tubers and higher plant vigor; later genotypes tend to be more productive and to accumulate higher dry matter (SILVA et al. 2018). It is probably due to the longer time to synthesize and store photoassimilates (RODRIGUES et al., 2009). But as for frying color, immature tubers tend to have higher levels of reducing sugars, as they have not yet been converted to starch (PEREIRA; CAMPOS, 1999). However, this relationship may be more or less evident, depending on the set of genotypes evaluated and other variables such as photoperiod during the production season. In a shorter photoperiod, the vegetative cycle is also shorter (RODRIGUES et al., 2009).

Therefore, for traits evaluated in this work, the most prominent clones differed with the region and the production system. Regarding clones for chipping, in the subtropical region represented by Canoinhas, none of the clones had better than or similar processing quality to 'Atlantic' to be considered for this type of use. However, in the high-altitude tropical region, represented by Brasilia, in conventional production system, clone F177-11-20 showed similar processing quality, and superior or similar marketable productivity to 'Atlantic', however it did not have a short vegetative cycle or less vigorous plants. In the organic system, the highlights were F177-11-20 and ORG7785 in processing quality and productivity, but their plants were more vigorous and had longer cycle than 'Atlantic'.

For french fry processing, in the subtropical region, the clones with superior or similar performance to 'Asterix', were F129-10-06 and F163-11-01, but had similar vegetative cycle and higher plant vigor. Clones F129-10-06, F16311-01, F177-11-20, ORG 6464, ORG 6377, F05-1103, Odone 80-02, F174-11- 01 and ORG 7785 were the most prominent, and among these F0511-03, Odone 80-02 and F177-11-20 had similar vigor, but a longer cycle than 'Asterix'. In organic production, F54-11-03, ORG 7785, F129-10-06, F163-11-01, F177-11-20, ORG 6464 were the best, however all of these showed longer cycle or higher plant vigor than 'Asterix'.

\section{Conclusions}

It was not possible to select clones with higher productivity, better quality of frying and at the same time early and not very vigorous, because higher yields and larger tuber sizes are associated with longer vegetative cycles and higher values of specific gravity, but lower (darker) frying color scores. Clones F129-10-06 and F163-11-01, were among the best clones for french fry processing in the subtropical region and in the high-altitude tropical region, in both production systems. Clones F129-10-06 and F16311-01 were similar to 'Asterix' in vegetative cycle but had more vigorous plants in the subtropical region, and had longer cycle and were similar in vigor in the high-altitude tropical region with conventional system, and were similar in cycle and plant vigor, in the organic system.

\section{References}

CIP. Procedimientos para pruebas de evaluación estándar de clones avanzados de papa: guía para colaboradores internacionales. Lima, Perú: Centro Internacional de la Papa. 2010, 152 p.

COUTO, J. R.; RESENDE, F. V.; SOUZA, R. B.; SAMINEZ, T. C. O. Instruções práticas para produção de composto orgânico em pequenas propriedades. Brasília: Embrapa Hortaliças, 2008. Comunicado Técnico 53.

CRUZ, C. D. Genes; a software package for analysis in experimental statistics and quantitative genetics. Acta Scientiarum Agronomy, v.35, p.271-276, 2013. https://doi.org/10.4025/actasciagron.v35i3.2125 1

FERNANDES, A. M.; SORATTO R. P.; SILVA. B. L. Extração e exportação de nutrientes em cultivares de batata. I - Macronutrientes. Revista Brasileira de Ciência do Solo, v.35, p.2039-2056, $2011 . \quad$ https://doi.org/10.1590/S010006832011000600020

HAVERKORT, A. J. Ecology of potato cropping systems in relation to latitude and altitude. Agricultural Systems, v.32, p.251-272, $1990 . \quad$ https://doi.org/10.1016/0308521X(90)90004-A 
KOOMAN, P. L.; FAHEN, M.; TEGERA P.; HAVEKORT A. J. Effects of climate on different potato genotypes. 1. Radiation interception, total and tuber dry matter production. European Journal of Agronomy, v.5, p.193-205, 1996. https://doi.org/10.1016/S1161-0301(96)02031-X

LAMBORO, A.; PETROS, Y.; ANDARGIE, M. Correlation and path coefficient analysis between yield and yield components in potato (Solanum tuberosum L.). Plant Science Today, v. 1, p. 196200, 2014.

https://doi.org/10.14719/pst.2014.1.4.79

MALLMANN, N.; LUCCHESI, L. A.; DESCHAMPS, C. Influência da adubação com NPK na produção comercial e rentabilidade da batata na região Centro-Oeste do Paraná. Applied Research \& Agrotechnology, v.4, p.67-74, 2012. https://doi.org/10.5777/paet.v4i3.1694

MOHAMMADI, R.; HAGHPARAST, R.; AGHAEE, M.; ROSTAEE, M.; POURDAD S. S. Biplot analysis of multi-environment trials for identification of winter wheat megaenvironments in Iran. World Journal of Agricultural Sciences, v.3, p. 475-480, 2007.

PÁDUA, J. G. D. E.; ARAÚJO, T. H.; DIAS, I. E.; CARMO, E. L.; da SILVA, H.; MESQUITA H. A. Aptidão de cultivares de batata holandesa para processamento na forma de fritura. Revista Raízes e Amidos Tropicais, v. 6, p. 1-10, 2010.

PALMER, M. W.; COOPER, J.; TÉTARD-JONES C.; SREDNICKA-TOBER, D.; ARANSKI, M.; EYRE, M.; SHOTTON; VOLAKAKIS, N.; OZTURK, I. C. L.; LEIFERT, C.; WILCOCKSON, S. J.; BILSBORROW. P. $E$. The influence of organic and conventional fertilization and crop protection practices, preceding crop, harvest year and weather conditions on yield and quality of potato (Solanum tuberosum) in a long-term management trial. European Journal of Agronomy, v.49, p.83-92, 2013. https://doi.org/10.1016/j.eja.2013.03.004

PEREIRA, A. S; CAMPOS. A. Sugar content in potato (Solanum tuberosum L.) genotypes. Ciência Rural, v.29, p.13-16, 1999. https://doi.org/10.1590/S010384781999000100003
PEREIRA, A. S.; NAZARENO, N. R. X.; SILVA, G. O.; BERTONCINI, O.; CASTRO, C. M.; HIRANO, E.; BORTOLETTO, A. C.; TREPTOW, R. O.; DUTRA, L. F.; LIMA, M. F.; GOMES, C. B.; KROLOW, A. C. R.; MEDEIROS, C. A. B.; CASTRO, L. A. S.; SUINAGA, F. A.; LOPES, C. A.; MELO P. E. BRSIPR Bel: Cultivar de batata para chips com tubérculos de boa aparência. Horticultura Brasileira, v. 33, p. 135139, 2015. https://doi.org/10.1590/S0102053620150000100022

PEREIRA, A. S.; SILVA, G. O.; CARVALHO A. D. F.; PONIJALEKI, R. S. Performance of advanced potato clones: plant vigor, tuber yield and specific gravity. Horticultura Brasileira, v. 35, p. 440-444, 2017. https://doi.org/10.1590/s0102053620170321

PEREIRA, A. S.; SILVA, G. O. Batata: evolução na oferta de cultivares brasileiras e na produção de tubérculos-semente. SeedNews, v. 23, p. 36-39, 2019.

RODRIGUES, G. B.; PINTO, C. A. B.; BENITES, F. R. G.; MELO D. S. Seleção para duração do ciclo vegetativo em batata e relação com a produtividade de tubérculos. Horticultura Brasileira, v.27, p.280-285, 2009. http://dx.doi.org/10.1590/S010205362009000300003

SILVA, G. O.; PEREIRA, A. S.; CARVALHO, A. D. F. Seleção de clones de batata para fritura com base em índices de seleção. Ceres, v. 61, p. 941-947, 2014. https://doi.org/10.1590/0034737X201461060008

SILVA, G. O.; PEREIRA, A. S.; SOUZA, V. Q.; CARVALHO, F. I. F.; FRITSCHE NETO, R. Correlações entre caracteres de aparência e rendimento e análise de trilha para aparência de batata. Bragantia, v.66, p.381-388, 2007. http://dx.doi.org/10.1590/S000687052007000300003

SILVA, G. O.; CARVALHO, A. D. F.; PEREIRA, A. S.; RAGASSI C. F.; AZEVEDO, F. Q. Desempenho de clones avançados de batata para rendimento de tubérculos em quatro ambientes. Revista Agro@mbiente, v.11, p.323-330, 2017. http://dx.doi.org/10.18227/19828470ragro.v11i4.4209 
SILVA, G. O.; PEREIRA, A. S.; AZEVEDO, F. Q.; CARVALHO, A. D. F.; PINHEIRO, J. B. Selection of potato clones for tuber yield, vine maturity and frying quality. Horticultura Brasileira, v.36, p. 276-281, 2018. http://dx.doi.org/10.1590/s0102-053620180222

SILVA, G. O.; PEREIRA, A. S.; AZEVEDO, F. Q.; CARVALHO, A. D. F.; PINHEIRO, J. B. Selection of Canadian potato clones for agronomic and frying quality traits. Horticultura Brasileira, v. 37, p. 423-428, 2019. http://dx.doi.org/10.1590/s0102053620190410

SILVA, G. O.; PEREIRA, A. S.; AZEVEDO, F. Q.; CARVALHO, A. D. F.; CASTRO, C. M.; HIRANO, E. Seleção de clones canadenses de batata para caracteres agronômicos e de qualidade de fritura, no Sul do Brasil. Revista Latinoamericana de la Papa, v. 24, p. 50-60, 2020.

SILVA, L. A. S.; PINTO, C. A. B. P. Duration of the growth cycle and the yield potential of potato genotypes. Crop Breeding and Applied Biotechnology, v.5, p.20-28, 2005. https://doi.org/10.37066/ralap.v24i1.389

TERRES, L. R.; NEY, V. G.; CERIOLI, M. F.; PEREIRA, A. S.; TREPTOW R. O. Respostas esperadas de seleção para cor de fritura em quatro populações híbridas de batata. Horticultura Brasileira, v. 30, p.300-303, 2012.

http://dx.doi.org/10.1590/S0102-

05362012000200019 